\title{
Szélerózió okozta talaj-, humusz- és tápanyag-áthalmozás különbségeinek feltárása különböző szerkezeti adottságú csernozjom talajokon terepi szélcsatorna kísérletek alapján
}

\author{
*FARSANG Andrea, BARTA Károly, SzATMÁri József, BARTUS Máté
}

Szegedi Tudományegyetem, Geoinformatikai, Természet- és Környezetföldrajzi Tanszék, Szeged

(Beérkezett: 2021.04.16.; Elfogadva: 2021.09.08.)

(Online megjelent: 2021.09.27.)

\section{Bevezetés}

Több kutatás is megerősíti, hogy a széleróziós károk nem csupán a homok területeket érintik, hanem más, homokos vályog, vályog fizikai féleségű talajokon is jelentős károk keletkezhetnek (BODOLAYNÉ 1965; BODOLAYNÉ, et al. 1976; LÓKI, SZABÓ 1996, 1997; LÓKI 2000, 2003a, b; BACH 2008, FARSANG, et al. 2013). A nemzetközi kutatások kezdetben elsősorban az arid, szemiarid területek homoktalajaira koncentráltak (VAN DONK, SKIDMORE 2001; MARSI, et al. 2003; RIKSEN 2004; BOUZA, et al. 2011), s Magyarországon is hosszú ideig az Alföld futóhomok területei álltak a vizsgálatok központjában (BORSY 1972; SZATMÁRI 1997, 2005; LÓKI, SCHWEIZER 2001; MEZÖSI, SZATMÁRI 1998; MuCSI, SZATMÁRI 1998). A 90-es évektől már szélcsatorna kísérletekre alapozva mind nemzetközi, mind pedig hazai kutatások sora foglalkozott a különböző fizikai féleségü talajok defláció érzékenységének vizsgálatával. MOVAHEDAN, et al. (2012) a homok fizikai féleségü talajon $212 \mathrm{~kg} \mathrm{~m}^{-2} / \mathrm{e} v$, homokos vályog talajon $3,5 \mathrm{~kg} \mathrm{~m}^{-2} / \mathrm{e} v$, agyagos vályog talajon pedig $2,3 \mathrm{~kg} \mathrm{~m}^{-2} /$ év talajveszteséget mértek. LÓKI (2003b) 123 hazai talajmintán végzett szélcsatorna kísérletsorozattal határozta meg a különböző fizikai féleségü talajok indítósebességét, mely fogalom alatt azt a szélsebességet értjük, amely mellett az adott talajra ható szél elmozdítja a talaj szemcséit. A homoktalajokra (23 minta) $6,18 \mathrm{~m} \mathrm{~s}^{-1}$, a homokos vályog talajokra (22 minta) $8,58 \mathrm{~m} \mathrm{~s}^{-1}$, a vályog talajokra (50 minta) $9,28 \mathrm{~m} \mathrm{~s}^{-1}$, az iszapos agyagos vályog talajokra pedig (7 minta) $9,84 \mathrm{~m} \mathrm{~s}^{-1}$ indítósebesség átlagértékeket kapott (LÓKI 2003b). A széleróziós kutatások kezdetben elsősorban a szediment transzport számszerüsítésére törekedtek. Annak meghatározására, hogy a különböző környezeti és antropogén hatások függvényében mennyi anyag erodálódik, szállítódik és rakódik le. Azonban fontos kérdés az elszállított anyag mennyiségén túl annak elemösszetétele, szerves- és tápanyag, valamit esetleges szennyezőanyag (nehézfém, peszticid stb.) tartalma is. E téma komolyabb vizsgálata a nemzetközi szintéren a '80-as években indult meg (ZOBECK, FrYREAR 1986; ZOBECK, et al. 1989; LARNEY, et al. 1998; BACH 2008). Ezen korai vizsgálatok a szediment szemcseméretét, valamint táp- és szervesanyag feldúsulási faktorát vizsgálták a csapdázott magasság függvényében. Később

*Levelezö szerzö: FARSANG ANDREA Szegedi Tudományegyetem, Geoinformatikai, Természet- és Környezetföldrajzi Tanszék, 6722 Szeged, Egyetem u. 2.

E-mail: farsang@geo.u-szeged.hu 
ZOBECK és munkatársai (1989) újabb kutatásuk eredményeként megállapították, hogy a különböző mezőgazdasági művelési módok nem csak a szélfútta üledék mennyiségére, hanem a magasságbeli eloszlására is hatással vannak (ZOBECK, FRYREAR 1986; ZOBECK, et al. 1989). LÓKI (2003a) laboratóriumi szélcsatorna kísérletei alapján megállapította, hogy a hordalékszállítás (1. ábra) a jól osztályozott futóhomoknál és az egyéb genetikai talajtípusoknál másképpen megy végbe. Niger területén végzett kutatásokat STERK és munkatársai (1996) különböző magasságintervallumokat különböztettek meg az alapján, hogy az egyes magasságokban melyik részecskeszállítási mód a meghatározó:

1. szaltáció domináns $(0-0,15 \mathrm{~m})$

2. szaltáció és lebegtetés egyforma fontosságú $(0,15-0,85 \mathrm{~m})$

3. lebegtetés domináns $(0,85-1 \mathrm{~m})$

4. csak lebegtetés $(1 \mathrm{~m}-)$.

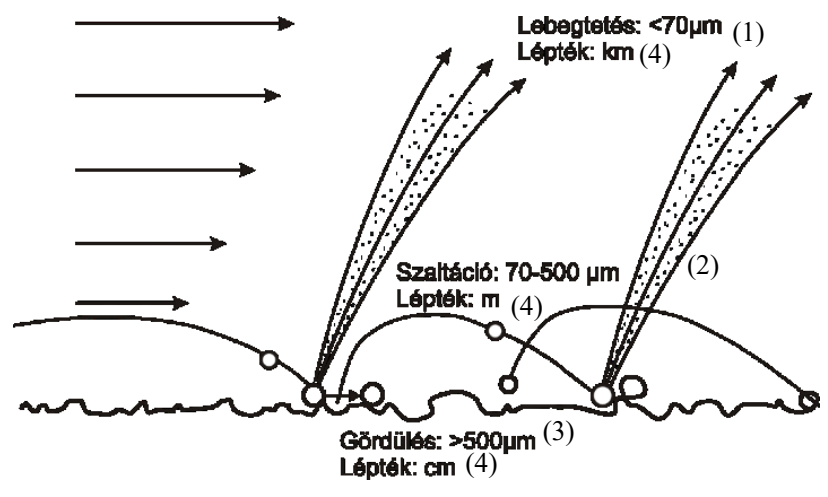

1. ábra

A szélerózió fó szállitási módozatai tekintettel a szemcseátméröre és a szállitási távolságra (LÓKI (2003) és MENDEZ, et al. (2011) nyomán)

A különböző nagyságú szerkezeti elemek elmozdulását tekintve megállapítható, hogy a gördülő mozgás azokra a szemcsékre vagy aggregátumokra igaz, amelyek túl nehezek ahhoz, hogy a szél felemelje, s szaltáció útján mozgassa öket. Általában 0,5-20 mm méretű szemcsékre vonatkozik ez, de befolyásolja ezt az anyag sűrüsége is (LÓKI 2003b). Kimutatták, hogy a mozgó anyag mennyiségének kb. 7-25\%-a így közlekedik, függően a szél erejétől, ill. a szemcseösszetételtől. A pattogva ill. szaltálva mozgás a leggyakoribb üledékszállítási forma, az esetek 80-90\%-ában így közlekedik az üledék (LÓKI 2003b). Általában a 100-500 ㅆ közötti szemcséket szállítja így a szél.

STERK és munkatársai (1996) számításai szerint a legnagyobb tömegü tápanyagvesztés az első magasság osztályban $(0-0,15 \mathrm{~m})$ következik be. Ez a kisebb aggregátumoknak köszönhetö, melyek csak szaltálva képesek elmozdulni, ugyanakkor nagyobb tömegüknél fogva több tápanyag mobilizálódik velük. A 4 . osztályba tartozó részecskék ugyan egy nagyságrenddel alacsonyabb tápanyag tömegfluxust mutatnak, ám sokkal messzebbre juthatnak a levegőben, ezáltal 
visszanyerhetetlenné válik az a tápanyag mennyiség, ami így mobilizálódik (STERK, et al. 1996). Azt is meg kell jegyezni, hogy ezen esetben az egységnyi tömegü szedimentnek nagyobb tápanyag-koncentrációja van, hiszen az elmozduló finomabb frakció fajlagos felülete nagyobb, a megkötődött tápanyag mennyiségére is pozitívan hat (STERK, et al. 1996).

A deflációs események hatására bekövetkező „on-site” és „off-site” hatások szerteágazóak (GoOSSENS, et al. 2000; BACH 2008). Ezen hatásokat az 1. táblázatban összefoglalva mutatjuk be.

\section{1. táblázat}

A deflációs események hatására bekövetkezö „,on-site” és ,off-site” hatások. (FARSANG (2016), GOOSSENS, et al. (2000) valamint BACH (2008) nyomán)

\begin{tabular}{|c|c|}
\hline „on-site” hatások & „off-site” hatások \\
\hline $\begin{array}{l}\text { Talajdegradáció } \\
\text { a finomabb talajrészecskék szelektív } \\
\text { elhordása a talajfelszínről, a durvább } \\
\text { frakció felhalmozódása } \\
\text { szervesanyag elhordás } \\
\text { tápanyag veszteség } \\
\text { a talajfelszín vízkapacitásának csökkenése } \\
\text { talajszerkezet romlása } \\
\text { akkumulálódott eolikus homok és por a } \\
\text { talajképződési folyamatokat befolyásolja } \\
\text { (eltemetett talajok) }\end{array}$ & $\begin{array}{l}\text { Rövidtávú hatások } \\
\text { látástávolság csökkenése, közlekedés } \\
\text { veszélyeztetése } \\
\text { talajanyag felhalmozódása az úttesten, az } \\
\text { út-menti árkokban, csatornahálózatban } \\
\text { porfelhalmozódás a lakókörnyezetben, } \\
\text { házakban } \\
\text { por behatolása különböző technikai } \\
\text { eszközökbe, gépekbe, jármüvekbe } \\
\text { mezőgazdasági haszonnövények minőségi } \\
\text { romlása a porfelhalmozódás következtében }\end{array}$ \\
\hline $\begin{array}{l}\text { Abrázió okozta károk } \\
\text { a növényi hajtások direkt abráziója, termés } \\
\text { minőségi és mennyiségi romlása } \\
\text { szélerózió kitakarhatja a gyökereket } \\
\text { További kárhatások } \\
\text { növényi kórokozók és/vagy kártevők } \\
\text { (talajszemcsékhez kötött) átmozgatása } \\
\text { eddig még nem érintett területekre } \\
\text { növényi hajtások betakarása } \\
\text { talajakkumuláció a parcellahatárokon, } \\
\text { vízelvezető árkok feltöltődése }\end{array}$ & $\begin{array}{l}\text { Hosszútávú hatások } \\
\text { a por belélegzése okozta légzőszervi } \\
\text { megbetegedések } \\
\text { nehézfémek és más potenciálisan toxikus } \\
\text { anyagok felhalmozódása, táplálékláncba } \\
\text { kerülése } \\
\text { a talaj- és felszíni vizek kontaminálódása } \\
\text { a felszíni vizek eutrofizációja }\end{array}$ \\
\hline
\end{tabular}

A szélerózió által okozott tápanyag és szervesanyag elhordás számszerüsítése mind a szélerózió off-site környezeti hatásainak értékelésében, mind pedig az on-site hatások, pl. az okozott gazdasági kár (tápanyagpótlás) megítélésében rendkívül fontos (FARSANG, et al. 2011, 2013). A növényi tápanyagok közül a nitrogén, foszfor és a kálium sorsát, veszteségeit, környezetterhelését kíséri megkülönböztetett figyelem. NEEMANN (1991) becslései szerint egy erős szélesemény alkalmával talajtípustól és a feltalaj tápanyag tartalmától függően akár 10-162 $\mathrm{kg} \mathrm{ha}^{-1} \mathrm{~N}$, 30-246 kg ha ${ }^{-1} \mathrm{P}_{2} \mathrm{O}_{5}, 27-237 \mathrm{~kg} \mathrm{ha}^{-1} \mathrm{~K}_{2} \mathrm{O}, 35-210 \mathrm{~kg} \mathrm{ha}^{-1} \mathrm{MgO}$, és 115-642 $\mathrm{kg} \mathrm{ha}^{-1} \mathrm{CaO}$ hatóanyagban kifejezett tápanyagvesztés is sújthatja a mezőgazdasági 
területeket. Rendkívül fontos gazdasági és környezetvédelmi tényezőről van tehát szó, ha meggondoljuk, hogy Magyarországon a széleróziótól erősen veszélyeztetett területek aránya mintegy $17 \%$, a kis és közepesen veszélyeztetetteké együttesen pedig meghaladja az ország területének $40 \%$-át (LÓKI 2003b).

A kiindulási talaj, valamint a szél által elszállított szediment tápanyagtartalma közötti összefüggést a feldúsulási viszonyaikkal jellemezhetjük (ZOBECK, FRYREAR 1986). Számos kutatásban a feldúsulási faktort, mint a talaj termékenység csökkenési indexét használják (LARNEY, et al. 1998). JUNRAN et al. (2009) a szélerózió hatását a talaj szemcseeloszlás változására tekintettel vizsgálták új-mexikói mintaterületen tartamkísérletekben. Megállapították, hogy már 2 év alatt a feltalaj textúrája érzékelhetően, kimérhetően durvábbá vált, a 250-500 $\mu \mathrm{m}$-es szemcsék aránya megnőtt a feltalajban, míg az 50-125 $\mu \mathrm{m}$, valamint az $50 \mu \mathrm{m}$ alatti tartomány szignifikánsan csökkent. Hasonló tendenciát követett a finom frakcióhoz kötődő vizsgált elemek viselkedése is.

LEYS és MCTAINSH (1994) Ausztráliában végzett kísérletei során a széleróziós események kapcsán fellépő szediment-elmozdulásban 16-szoros $\mathrm{N}$ - és 11-szeres szervesanyag-feldúsulást regisztráltak. Ezen értékek gazdasági, ill. tápanyagutánpótlási szempontból sem elhanyagolhatóak.

STERK és munkatársai (1996) nigeri terepi kísérleteiben a tápanyag-elhordódás és a szedimentszállítási magasságok közötti összefüggéseket vizsgálták. Megállapították, hogy a szaltálva szállított talajrészecskék szerepe a tápanyagáthalmozásban fontos, valamint, hogy a $0,5 \mathrm{~m}$-rel a terepszint felett elhelyezett szedimentcsapdákban összegyült anyagban a kiindulási talajanyaghoz képest háromszoros volt a tápanyag-feldúsulás, a $2 \mathrm{~m}$ magasan elhelyezett csapdákban viszont már 17-szeres.

Ezen kutatások túlnyomó része elsősorban a homok fizikai féleségű talajtípusokra koncentrál. A szélerózió azonban okozhat károkat a finomabb fizikai féleségü talajfelszíneken is, mint pl. a leromlott szerkezetü csernozjom talajokon. Különösen a kora tavaszi gyér növényborítottság melletti szélerózió okoz jelentős veszteségeket a tápanyagmérlegben.

Kutatásunk során Magyarország dél-alföldi csernozjom talajú területeit vizsgáltuk azon céllal, hogy in situ körülmények között számszerüsítsük a különböző szélesemények által okozott talajveszteség mértékét, a feltalaj agronómiai szerkezetében bekövetkező változásokat, valamint az ezzel együtt járó humusz- és tápanyag-áthalmozás nagyságrendjét.

Kutatásunk célkitüzései az alábbiak voltak: terepi szélcsatornás mérésekre alapozott laboratóriumi mérések alapján különböző szerkezeti állapotú csernozjom talajokra meghatározni:

- a indítósebességet,

- a szélerózióval áthalmozott szedimentben mért makro-, mikroelem, és humuszanyag feldúsulását,

- valamint az ezekre ható talajtani tényezőket. 


\section{Anyag és módszer \\ Mintaterületek}

Apátfalva külterület

Terepi szélcsatornás méréseinkhez Békés megyében, Makótól K-re mintegy 10 km-re Apátfalva külterületen kiválasztottunk egy humusz- és tápanyagtartalmát tekintve jó minőségủ réti csernozjom talajú parcellát, amely szántó (kukorica) müvelés alatt áll. (2. ábra). Végeztünk vizsgálatokat mind csupasz felszínen, mind pedig a kukorica sorok felett is, de jelen tanulmányban a növényborítás-mentes felszínre vonatkozó eredményeinket használjuk fel, hogy összehasonlítható legyen a szegedi kísérleti körülményekkel.

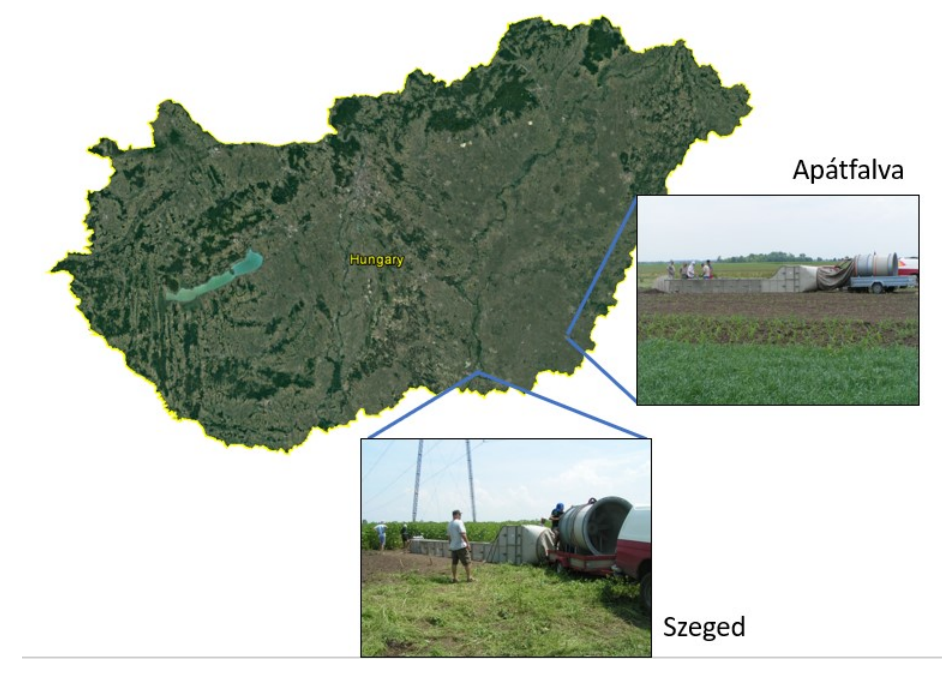

2. ábra

Mobil szélcsatornás vizsgálatok helyszinei Apátfalván és Szegeden

Apátfalva a Marosszög kistájon helyezkedik el, mely kistáj 78 és $88 \mathrm{~m}$ közötti tszf-i magasságú, ártéri szintü tökéletes síkság. A felszínen 8-15 m vastagságban holocén képződmények találhatók, főként ártéri iszap, agyag, homokliszt. A magasabb térszínek pleisztocén löszborításán jó minőségủ csernozjom talajok alakultak ki. Meleg, száraz éghajlatú terület. Az évi csapadék összeg Makó térségében kevéssel meghaladja a $600 \mathrm{~mm}$-t. Az ariditási index 1,2 körüli. A jellemző szélirányok az É-i, D-i és DK-i szelek, az átlagos szélsebesség 2,5 és 3,0 $\mathrm{m} \mathrm{s}^{-1}$ közötti. A jellemző talajvízállások általában 1-3 m mélyen találhatók (DÖVÉNYI 2010).

A vizsgált területre a löszös üledéken kialakult réti csernozjom talajok előfordulása jellemző. E talajtípus kialakulására és tulajdonságaira jellemző, hogy a csernozjom jellegü humusz-felhalmozódás gyenge vízhatással kísért. Ennek oka lehet egyrészt a talajvíz közelsége, másrészt a mélyedésekben összefutó belvíz. A vízhatás jelei, a vasszeplők és a rozsdás foltok részben az A szintben, részben a talajképző kőzetben jelennek meg. Vízgazdálkodása az év egy részében a talajvíz 
felszín felé áramlásával jellemezhető. Az egyes szintek jó vízáteresztőek, megfelelő víztartó képességüek.

\section{Szeged külterület}

2013 nyarán terepi szélcsatornás kísérleteket végeztünk a Szegedtöl ÉNy-ra elhelyezkedő szántó (napraforgó) területen (2. ábra). A vizsgált terület az AlsóTisza-vidék középtájon, $\mathrm{s}$ ezen belül a Dél-Tisza-völgy kistájon található. Domborzatára jellemző a $80-101 \mathrm{mBf}$ tengerszint feletti magasság, amely a Tisza irányába lejtő tökéletes síkság (DövÉNYI 2010). Éghajlata meleg, száraz. A táj jellemző ariditási indexe 1,2-1,3. A jellemző szélirányok sorra az ÉNy-i, DK-i, amelyek a $7 \mathrm{~m} \mathrm{~s}^{-1}$-os szélerősséget meghaladó (erozív) széleseményekre kifejezetten jellemzök. Az átlagos szélsebesség $3 \mathrm{~m} \mathrm{~s}^{-1}$ körül alakul. A terület talajtípusa löszön kialakult réti csernozjom. A vizsgált területek talajvízállása általában 1-4 m között ingadozik. A víz hatására utaló hidromorf bélyegek, a vasszeplők és rozsdafoltok zömmel csak a C-szintben találhatók.

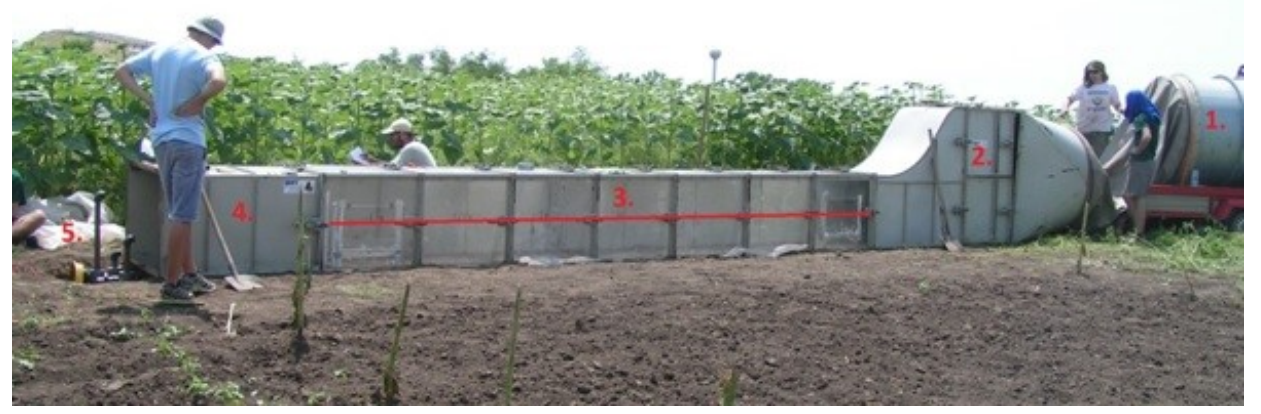

3. ábra

Szélcsatorna (részei: 1. ventilátor, 2. laminátor, 3. szélcsatorna elemek, 4. szedimenttálca, 5. szélcsatorna kimeneti nyilása, csapdázók területe)

\section{Módszerek}

Az in situ szélcsatornás kísérleteinket 2011. júniusában Apátfalván, valamint Szegeden 2013 júliusában végeztük. A terepi kísérletsorozatokhoz egy $12 \mathrm{~m}$ hosszú, $0,7 \mathrm{~m}$ széles és $0,75 \mathrm{~m}$ magas szélcsatornát használtunk. A szélcsatorna több részböl állt. Egy nagy teljesítményü, $1,2 \mathrm{~m}$ átméröjü ventilátor biztosította a légáramlatot, melyet egy $7,5 \mathrm{~kW}$-os villanymotor hajtott meg. A nagyfeszültségü áramot aggregátor szolgáltatta. A ventilátort egy flexibilis cső követi, amely egy ún. laminátor részhez csatlakozott $\mathrm{A}$ laminátor egy fémvázból és hálószerủen egymásra telepített csövekből állt. Funkciója a ventilátor által keltett turbulens áramlás laminárissá tétele. A laminátort egy szúkítő elem követte, amely immár egyenes vonalú légáramlatot vezette egy héttagú (egyenként 80 × 70 x $75 \mathrm{~cm}$, összesen 5,6 m hosszú), alul nyitott szélcsatornába. A szélcsatorna által megfújt talajfelszín összesen $3,92 \mathrm{~m}^{2}$ nagyságú volt. A 7 db elemből álló szélcsatornatest egyik oldala átlátszó 
műanyagból készült, így megfigyelhetővé vált a talaj mozgása. Az elemek után egy tálcarész következett, amely a görgetve mozgó részecskék gyüjtésére alkalmas. A szuszpendálva és szaltálva szállított talajszemcsék mintázásához a szélcsatorna kimeneti nyílásába csapdákat helyeztünk. A 3. ábrán a terepi mintavételen használt szélcsatorna látható.

A terepi kísérleteket egy legalább 10 nap hosszú csapadékmentes időszak után végeztük, mikor a talaj légszáraz állapotúvá vált (nedvesség tartalom átlaga 7-8 v/v\%). A méréseket növényborítás mentes felszíneken végeztük, minden mérés esetén, mielőtt ráhelyeztük a szélcsatornát a felszínre, a feltalajt átgereblyéztük. Minden esemény 10 perc hosszú fújatási kísérletből állt. Kísérleteinket a indítósebesség megállapítását követően 4900-5100-as fordulatszámon, mintegy 14-15 $\mathrm{m} \mathrm{s}^{-1}$ közötti (30 $\mathrm{cm}$ magasan mért) szélsebességen végeztük. A szélsebességet minden fúvatás során horizontális és vertikális profilokban is mértük (4.ábra). A mérés Lambrecht Jürgens 642 típusú anemométer segítségével történt. Minden kísérlet előtt (E) és után (U) mintáztuk a talajfelszínt $(0-5 \mathrm{~cm})$ a turbinától távolodva három ponton (E1, E2, E3, U1, U2, U3).

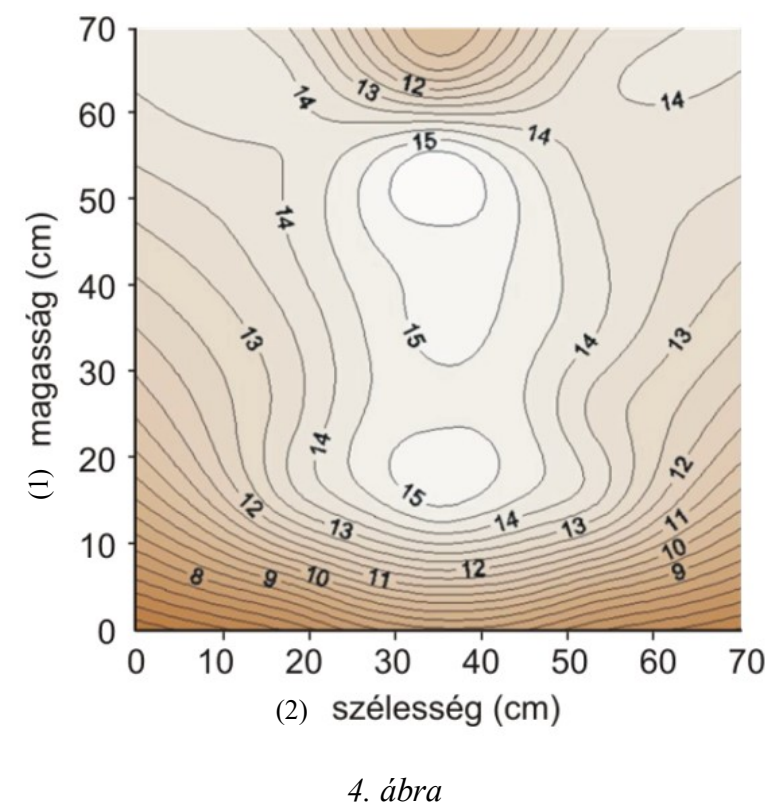

Az apátfalvi mérések jellemzö szélprofiljai, a szélsebesség $\left(\mathrm{m} \mathrm{s}^{-1}\right)$ izovonalas ábrázolása a szélcsatorna keresztmetszetében a csupasz talajfelszín felett

A fújatási kísérleteket követően mintáztuk a görgetve szállítódó frakciót, mely a szélcsatorna végénél elhelyezett süllyesztett peremes ládában gyült össze, valamint ürítettük a szélcsatorna végénél elhelyezett csapdákat (5. ábra). Kétféle csapdázót használtuk méréseinkhez: az MWAC (Modified Wilson and Cook) csapdasorozatot (6. ábra), valamint az általunk kifejlesztett, majd szabadalmi eljárás alá helyezett WAST (Wet Active Sediment Trap) csapdázót (7. ábra). 
Felülnézet

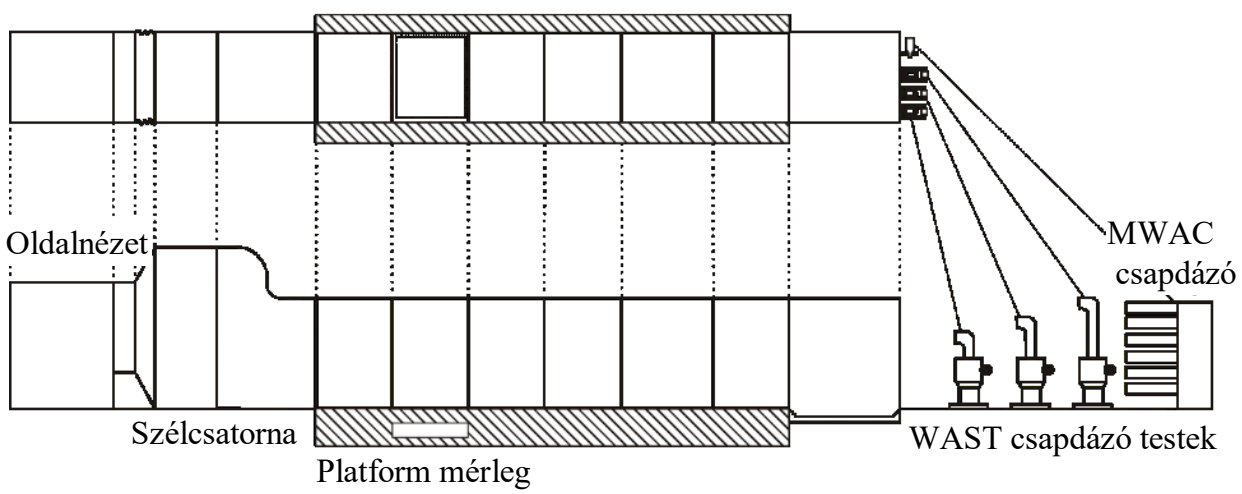

5.ábra

A kísérleti eljárásban alkalmazott eszközkombináció felül- és oldalnézetben (szélcsatorna, platform mérleg, MWAC csapdázók, WAST csapdázók)

A homoktalajok csapdázására kifejlesztett, a szakirodalomból jól ismert eszköz a Modified Wilson and Cook (MWAC) csapdázó (GoossENS, et al. 2000) (6. ábra). Az eszköz egy mintázó palackból, valamint bemeneti és kimeneti csövekböl áll. A palackot vertikális és horizontális csapdázásra egyaránt lehet használni. Az eszköz müködési elve az eszköz belsejében a légáram sebességének lecsökkenésén alapul. A bemeneti cső a szél áramlásával ellentétes irányban nyitott annak érdekében, hogy a szálló anyag be tudjon áramlani rajta. Mivel a bemeneti és kimeneti cső átmérője kisebb, mint a palacké, a nyomáscsökkenés miatt a szemcsék jelentős hányada leülepedik a palackban, miközben viszonylag tiszta levegö távozik a kimeneti csövön. Az MWAC elemei 5, 15, 25, 35, 45, 55 cm magasságokban helyezkedtek el.
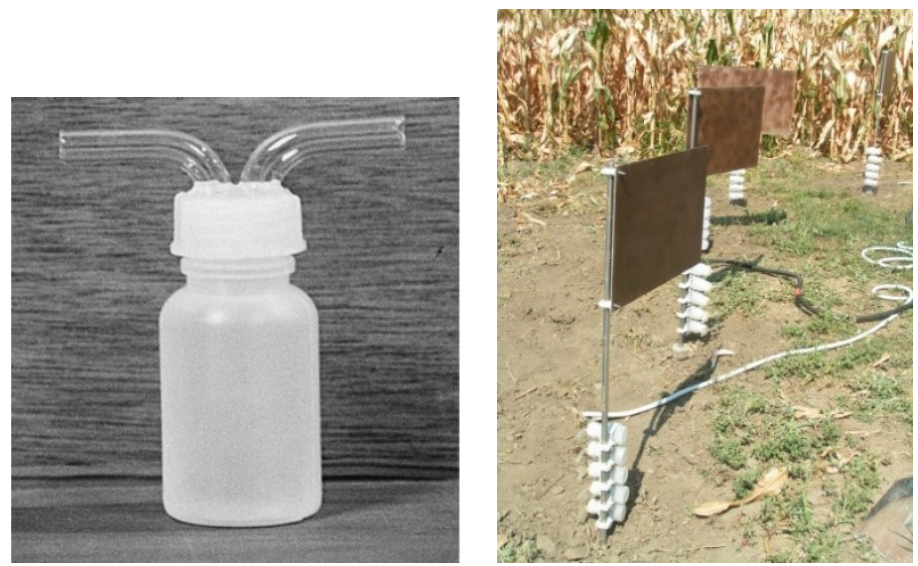

6. ábra

Wilson and Cooke csapda (GoOSSENS, et al. (2000) csapdatest (bal oldal) és az apátfalvi területre kitelepitett csapdázók (jobb oldal)) 
A WAST (7. ábra) egy általunk kifejlesztett, szabadalmaztatott horizontális aktív csapda, mely különböző magasságokban történő mintázásra alkalmas, izokinetikus, nedves csapdázó. A WAST csapda szabadalmaztatását 2014-ben kezdtük meg, a folyamat 2020. január 21 -én ért véget. A szabadalmi bejelentés száma: 9530/19, ügyszáma: P14 00292. Kísérletünkben a csapdák bemeneti nyílásai 5-10, 20-25, 50-55 cm magasságokban helyezkedtek el (7. ábra).
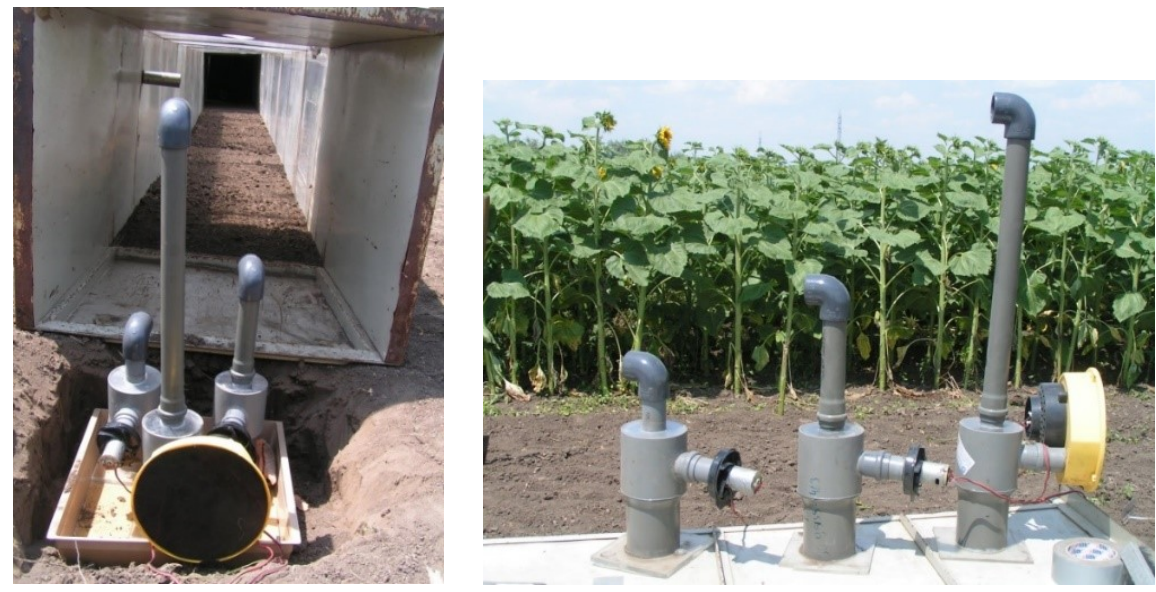

7. ábra

A 3 db WAST csapdázó különbözö mintázási magasságokra állítva

A laboratóriumi vizsgálatokat megelőzően a mintákat $25{ }^{\circ} \mathrm{C}$-on légszárazra szárítottuk, majd az egyes vizsgálatokhoz kapcsolódó szabványban előírt előkészítést követöen a következő talajtani paramétereket határoztuk meg: aggregátum méreteloszlás szitálással; Arany-féle kötöttségi szám MSZ-08-0205:1978 szabvány szerint; $\mathrm{pH}\left(\mathrm{H}_{2} \mathrm{O}\right)$, karbonát-tartalom MSZ-08-0206/2:1978 szerint; szervesanyagtartalom MSZ 21470/52:1983 szerint. A szemcseösszetétel méréseket a talajminták esetében, ahol volt elég mennyiség a méréshez, a hagyományos pipettás módszerrel végeztük MSZ-08-0205:1978 alapján (8.-9.ábra). A pipettás mérések előtt a szerves anyag roncsolásához 10\%-os hidrogén-peroxidot $\left(\mathrm{H}_{2} \mathrm{O}_{2}\right)$ használtunk, a karbonát $\left(\mathrm{CaCO}_{3}\right)$ roncsolásához 10\%-os sósavat $(\mathrm{HCl})$. A nagyobb magasságban elhelyezett csapdák esetében, ahol csak nagyon csekély, néhány grammnyi mennyiség gyült össze, a méréseket Particle sizer Analysette 22 MicroTec plus típusú, Fritsch gyártmányú lézer diffrakciós müszerrel végeztük. Előkészítésként 180 s-os előzetes ultrahangos kezelést $(\mathrm{f}=36 \mathrm{kHz}, \mathrm{P}=60 \mathrm{~W})$ alkalmaztunk a mérések megkezdése előtt. Minden egyes minta esetében 3 mérés történt és a mérések során is folyamatosan müködött az ultrahang. A müszerbe beépített zöld ( $\lambda=532 \mathrm{~nm}, \mathrm{P}=7 \mathrm{~mW})$ és IR ( $\lambda=940 \mathrm{~nm}, \mathrm{P}=9 \mathrm{~mW}$ ) lézerek kombinálásával történt a mérés $0,8-2000 \mu \mathrm{m}$-es tartományban. A mérések során a Fraunhofer-féle optikai modellt alkalmaztuk. A mérések során nem alkalmaztunk vegyszeres diszpergálást, elkerülendő a diszpergálószer által okozott zavaró hatásokat. Helyette a hosszabb ultrahangos 
kezelést alkalmaztunk. Az ismétlések között a D50 értékben mindössze 3-4 \% relatív szórást tapasztaltunk. A további elemzésekhez a három mérés átlagát használtuk fel.

Apátfalva

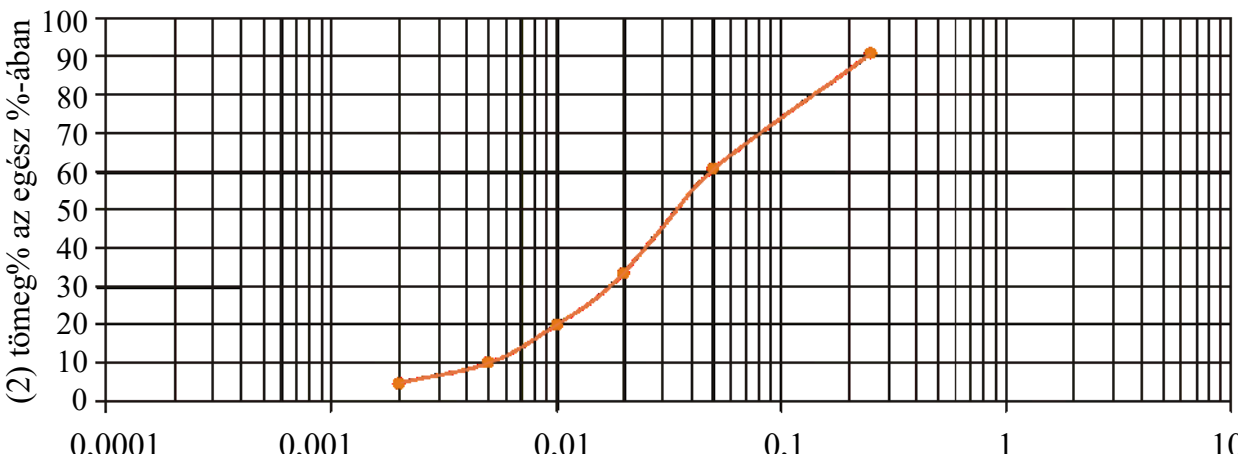

(1) szemcseméret $(\mathrm{mm})$

8. ábra

Az apátfalvi mintaterület talajának összetételét jellemzö szemeloszlási görbe

Szeged

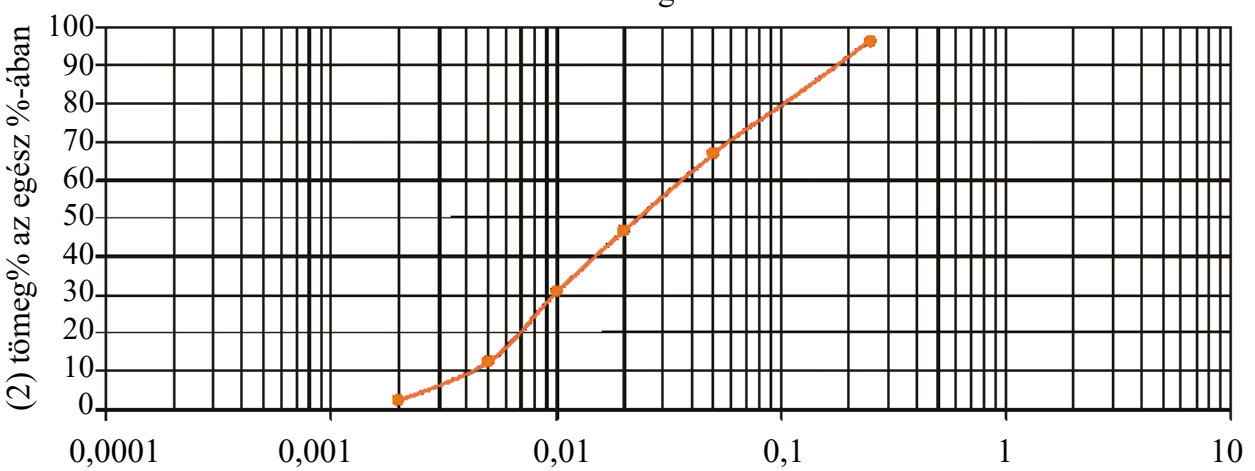

(1) szemcseméret (mm)

9. ábra

A szegedi mintaterület talajának összetételét jellemzö szemeloszlási görbe

A minták összes elemtartalmát röntgen fluoreszcens spektrofotometriás (XRF) módszerrel vizsgáltuk. A mérést megelőzően a mintákat homogenizáltuk, porítottuk achát mozsárban a $100 \mu \mathrm{m}$ alatti szemcseméret elérése céljából. A mérést a Szegedi Tudományegyetem Ásványtani, Geokémiai és Közettani Tanszékén végezték, egy Horiba gyártmányú, Jobin Yvon XGT 5000-es típusú röntgen fluoreszcens spektrométerrel. Az alábbi paraméterekkel történt a vizsgálat: a röntgen cső anyaga ródium, az anódáram $1 \mathrm{~mA}$, a gerjesztő feszültség $30 \mathrm{keV}$ volt. A gerjesztő nyaláb átméröje 100 mikron volt, a mérési idő $600 \mathrm{~s}$. A minta 2 különböző pontján történt párhuzamos mérés. 
A mintákból ammónium-laktátos oldattal határoztuk meg a növények által felvehető foszfor és kálium tartalmat, amit AL- $\mathrm{P}_{2} \mathrm{O}_{5}$-ban és AL- $\mathrm{K}_{2} \mathrm{O}$-ban adtunk meg. A mérés a felvehető foszfor esetében a hígítatlan oldatokból történt, Foss Fia Star 5000 áramlásos UV-VIS spektrofotométerrel. A felvehető káliumtartalom meghatározását Perkin Elmer 3110 atomabszorpciós és emissziós spektrométerrel végeztük.

A deflációval mozgó humusz, ill. egyes elemek (tápanyagok, toxikus elemek) feltalajban, vagy üledékben való dúsulásának mértéke feldúsulási faktorok (FF) segítségével becsülhető meg. A feldúsulási faktor (FF) a következő módon számolható:

$$
\mathrm{FF}=\mathrm{C}_{\text {szed }} / \mathrm{C}_{\text {talaj, }}
$$

ahol $\mathrm{C}$ a kérdéses elem koncentrációja $\left(\mathrm{mg} \mathrm{kg}^{-1}\right)$ a csapdázott szedimentben (szed) és a széleróziós esemény előtt (jelen esetben a szélcsatorna alatt) mintázott feltalajban $(0-5 \mathrm{~cm})$ (talaj). Ha a feldúsulási faktorok értéke 1 körüli vagy az alatti, akkor a kérdéses elem ill. humusz nem dúsul az erózióval elmozduló szedimentben, ha értéke egynél nagyobb, akkor az adott elem feldúsul.

\section{Eredmények értékelése és következtetések}

Elem elmozdulás: a szél általi tápanyag-áthalmozás mértékének összevetése délalföldi réti csernozjom talajokon

Az terepi szélcsatorna kísérletek alá vont két dél-alföldi réti csernozjom terület, bár talajtípusa, talajképző kőzete egyezést mutat, egyes talajtani alaptulajdonságaiban eltér egymástól.

Apátfalvánál a feltalaj fizikai félesége az Arany-féle kötöttségi érték alapján, agyag, összes só tartalma alacsony $(0,05 \%)$, kémhatása gyengén lúgos $(8,2)$, humusztartalma a feltalajban magas $(4,8 \%)$ (2. táblázat).

A vizsgált szegedi parcellán ásott szelvény adatai alapján a talaj fizikai félesége az Arany-féle kötöttségi érték alapján vályog. A humusztartalom a humuszos szintben közepes. A humuszos réteg vastagsága $60 \mathrm{~cm}$. Kémhatás gyengén lúgos és lúgos, a szelvény mélységével a $\mathrm{pH}$ értéke nő $\left(\mathrm{pH}_{\mathrm{H} 2 \mathrm{O}}=7,9-9,2\right)$. A $\mathrm{CaCO}_{3}$ tartalom 3,4-5,1\% között változik (2. táblázat) (FARSANG et al. 2011).

A talajok szemcseösszetétele alapján a háromszög diagramba elhelyezve a mért értékeket (Apátfalva agyag $6 \%$, iszap $28 \%$, homok $66 \%$, szegedi terület agyag $3 \%$, iszap $45 \%$, homok $52 \%$ ) megállapítható, hogy minkét terület talaja a homokos vályog textúra osztályba esik.

A két terület talajának a mechanikai összetételében a legnagyobb különbség a $10 \mu \mathrm{m}$-nél kisebb szemcsefrakció arányában mutatkozik: míg az apátfalvi területen a szemcsék $20 \%$-a tartozik ebbe a mérettartományba, addig a szegedi területen $30 \%$ (8. és 9. ábra). A vízoldható összes só értéke mindkét mintaterületen alacsony, 0,02-0,05 \% közötti értéket vesz fel (2. táblázat). 
2. táblázat

Az apátfalvi és szegedi kísérleti parcellák talajainak alapvizsgálata

\begin{tabular}{cccccc}
\hline & $\begin{array}{c}\text { Összsó } \\
\text { tartalom } \\
\mathbf{( \% ) ( 1 )}\end{array}$ & $\mathbf{p H}$ & $\begin{array}{c}\text { Karbonát } \\
\text { tartalom } \\
\mathbf{( \% )}(\mathbf{2})\end{array}$ & $\begin{array}{c}\text { Humusz } \\
\mathbf{\%}(\mathbf{3})\end{array}$ & $\begin{array}{c}\text { Kötöttség } \\
\mathbf{( K} \mathbf{A}) \mathbf{( 4 )}\end{array}$ \\
\hline $\begin{array}{c}\text { Apátfalva } \\
\mathbf{( 0 - 1 0 ~ c m )}\end{array}$ & 0,05 & 8,2 & 12,2 & $4,5-4,8$ & 51 \\
$\begin{array}{c}\text { Szeged } \\
\text { (szelvény } \\
\text { feltárás adatai) }\end{array}$ & $0,02-0,07$ & $7,9-9,2$ & $3,4-5,1$ & $2,2-3,7$ & $36-40$ \\
\hline
\end{tabular}

A LÓKI (2003b) által készített Magyarország potenciális széleróziós térképén mindkét terület a közepesen veszélyeztetett kategóriába esik, a „Kritikus indítósebesség értékei Magyarországon" c. térképlap alapján a területekre 8,6-10,5 $\mathrm{m} \mathrm{s}^{-1}$ a várható indítósebesség érték. A Szegedtől É-ra eső réti csernozjomokon a LÓKI (2003b) által is előjelzett, a csernozjom talajok fizikai félesége alapján prognosztizálható $6,5-9,0 \mathrm{~m} \mathrm{~s}^{-1}$ közötti indítósebesség értékeket mértünk, míg Apátfalván 13,0 $\mathrm{m} \mathrm{s}^{-1}$ volt az indítósebesség értéke. A különbség oka a két terület talajának eltérő humusz- és karbonáttartalma, melyek a talaj szerkezetének kialakításában, a stabil szerkezeti elemek képződésében nagy szerepet játszanak. Az apátfalvi terület talajának magasabb karbonát- és humusztartalma, valamint az aggregátum összetételében mért magasabb morzsa arány (3. táblázat) az indítósebességi érték növelésének irányába hatnak.

A két terület feltalajának mechanikai összetétele ugyan nem mutat jelentős eltérést (8. és 9. ábrák), de az aggregátum összetételében jelentős különbség van a $0,5 \mathrm{~mm}$ alatti és feletti szerkezeti elemek megoszlásában. Az apátfalvi területen feltehetően a szerkezeti elemek kötőanyagaként jelentős szerepet kapó magasabb $\mathrm{CaCO}_{3}$ - és humusztartalomnak köszönhetően - a $0,5 \mathrm{~mm}$ morzsaátméröt meghaladó szerkezeti elemek aránya 76,9\%, míg a szegedi területen ez az érték csupán $69,43 \%$. A $0,5 \mathrm{~mm}$-nél kisebb, tehát a szél hatására leginkább mozgékony szerkezeti elemek aránya a békési területen 23,1\%, Szegednél 30,57\% (3. táblázat) (FARSANG 2016).

\section{3. táblázat}

Az eredeti talajfelszín aggregátum összetétele a két vizsgált területen (tömeg\%, Apátfalva $n=10$, Szeged $n=10$ )

\begin{tabular}{rcccc}
\hline \multicolumn{1}{c}{$\mathbf{m m}$} & $\begin{array}{c}\text { Apátfalva felszín } \\
\mathbf{m} / \mathbf{m} \% \mathbf{( 1 )}\end{array}$ & $\begin{array}{c}\text { Apátfalva szórás } \\
\mathbf{( 2 )}\end{array}$ & $\begin{array}{c}\text { Szeged felszín } \\
\mathbf{m} / \mathbf{m} \% \mathbf{( 1 )}\end{array}$ & Szeged szórás (2) \\
\hline$>\mathbf{4}$ & 14,4 & 3,9 & 23,9 & 1,7 \\
$\mathbf{2}-\mathbf{4}$ & 18,4 & 1,7 & 9,5 & 1,5 \\
$\mathbf{1 - 2}$ & 25,1 & 1,2 & 18,4 & 1,9 \\
$\mathbf{0 , 5}-\mathbf{1}$ & 19,0 & 1,4 & 16,3 & 1,7 \\
$\mathbf{0 , 2 5 - 0 , 5}$ & 9,7 & 1,3 & 11,2 & 1,9 \\
$<\mathbf{0 , 2 5}$ & 13,4 & 2,6 & 19,37 & 1,5 \\
\hline
\end{tabular}


Ezt támasztják alá korábbi kísérleteink is (BARTUS et al. 2019), melyben közel 40 dél-alföldi mintavételi helyről származó talajminta szélcsatornában történő fújatása alapján állapítottunk meg összefüggéseket a talaj egyes tulajdonságai, valamint a kritikus indítósebessége és az adott talaj defláció érzékenysége között. Az agronómiai szerkezet másik fontos jellemzője a közepes aggregátumátmérő (D50). A közepes aggregátum átmérő és a kritikus indítósebesség között exponenciális kapcsolatot találtunk (10. ábra, $\left.\mathrm{R}^{2}=0,7504\right)$. A nagyobb méretủ aggregátumok jelenlétében lényegesen lassabban indul meg a szélerózió (BARTUS et al. 2019)

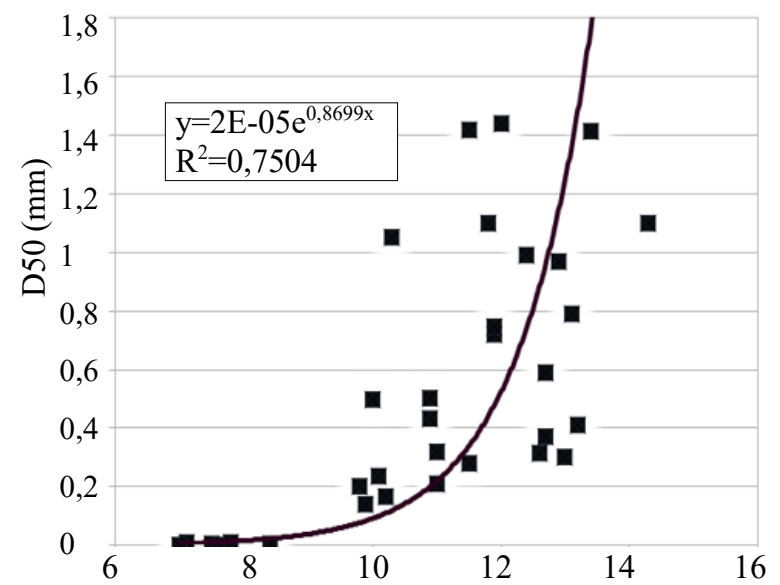

(1) szélsebesség $\mathrm{m} \mathrm{s}^{-1}$

10. ábra

A talaj közepes aggregátum átméröjének hatása a kritikus inditósebességre (BARTUS, et al. 2019)

$\mathrm{Az}$ aggregátum összetételben, valamint a humusz- és $\mathrm{CaCO}_{3}$ tartalomban megfigyelhetö különbségek hatására a Szeged melletti csernozjom mintaterület talaja defláció érzékenyebb. A feltalajban mért kisebb humusztartalom, valamint a $0,5 \mathrm{~mm}$ nél kisebb szemcsék magasabb aránya következtében kisebb indítósebesség értékeket, nagyobb áthalmozódó talajmennyiséget, valamint ezzel együtt nagyobb mennyiségü humusz- és foszfor elmozdulást mértünk az egységesen 10-10 perces fújatási kísérleteink alkalmával (4. táblázat) (FARSANG, 2016).

Különbség figyelhető meg továbbá az elszállítás módjában is: A kisebb szerkezeti elemekkel jellemezhető szegedi csernozjom területen a $13-15 \mathrm{~m} \mathrm{~s}^{-1}$-os szélesemények során a talajanyag áthalmozódása $\sim 2 \%$-ban görgetve történik, $\sim 51 \%$-a szaltálva és mintegy 47\%-a szaltálva és lebegtetve távozik a területről. Az apátfalvi szerkezetesebb talajú területen pedig a talajelmozdulás döntő többségét a görgetve szállított talajanyag teszi ki, s a szaltálva, ill. lebegtetve távozó frakció mennyisége a teljes talajmozgáshoz viszonyítva csupán 10,7-17,4\% között változik. 


\section{4. táblázat}

Az elmozduló talajanyag, a feldúsulási faktorok, valamint az elmozduló humusz és elemtartalom mennyiségének összevetése az apátfalvi és szegedi réti csernozjomon végzett kísérletekre vonatkozóan

\begin{tabular}{|c|c|c|c|c|c|c|}
\hline & & $\begin{array}{l}\text { Kritikus } \\
\text { indító- } \\
\text { sebesség } \\
\mathrm{m} \mathrm{s}^{-1}(1)\end{array}$ & $\begin{array}{c}\text { Áthalmozódó } \\
\text { talajmennyiség } \\
\text { (átlag) }\left(\mathrm{g} \mathrm{m}^{-2}\right)(2)\end{array}$ & $\begin{array}{c}\text { Koncentráció } \\
\text { a csapdázott } \\
\text { szedimentben } \\
\text { (3) }\end{array}$ & $\begin{array}{l}\text { Feldúsulási } \\
\text { faktor (4) }\end{array}$ & $\begin{array}{c}\text { Összes } \\
\text { humusz- / } \\
\text { elemát- } \\
\text { halmozódás } \\
\left(\mathrm{g} \mathrm{m}^{-2}\right)(5)\end{array}$ \\
\hline \multirow{3}{*}{ 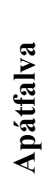 } & H\% & \multirow{3}{*}{13} & \multirow{3}{*}{115,1} & 4,8 & 1,07 & 5,5 \\
\hline & $\begin{array}{c}\mathbf{P} \\
(\mathbf{p p m})\end{array}$ & & & 884 & 0,98 & 0,11 \\
\hline & $\begin{array}{c}\text { K } \\
(\mathbf{p p m})\end{array}$ & & & 16344 & 1,08 & 1,61 \\
\hline \multirow{3}{*}{ 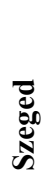 } & H\% & \multirow{3}{*}{$6,5-9,0$} & \multirow{3}{*}{343,2} & 2,7 & 1,1 & 6,9 \\
\hline & $\begin{array}{c}\mathbf{P} \\
(\mathbf{p p m})\end{array}$ & & & 2268 & 1,2 & 0,78 \\
\hline & $\begin{array}{c}\mathrm{K} \\
(\mathrm{ppm})\end{array}$ & & & 40801 & 1,05 & 13,9 \\
\hline
\end{tabular}

A humusz- és elemáthalmozódás mértéke tekintetében nagy különbségek nem adódtak a két csernozjom talajú terület között. Az egy-egy erozív szélesemény alkalmával regisztrálható humusz elmozdulás $5,5-6,9 \mathrm{~g} \mathrm{~m}^{-2}$, a P $0,1-0,8 \mathrm{~g} \mathrm{~m}^{-2}$, a K elmozdulás pedig 1,6-13.9 $\mathrm{g} \mathrm{m}^{-2}$. Ezen értékek nagyságrendi egyezést mutatnak STERK et al. (1996) terepi, on-site technikával kapott mérési eredményeivel (5. táblázat). BIELDERS és munkatársai (2002) tápanyag-áthalmozásra kapott eredményei kb. egy nagyságrenddel kisebbek. Ennek oka, hogy Nigériában folytattak kutatásokat tápanyag szegény homokos területen. Vizsgálataik középpontjában a szélfútta üledék mennyiségének és minőségének térbeli változása állt a szélút függvényében.

\section{5. táblázat}

A P és K áthalmozódási értékek összevetése egyes kutatók által megállapított széleróziós tápelem veszteségekkel

\begin{tabular}{lll}
\hline & $\mathbf{P}\left(\mathbf{g ~ m}^{-\mathbf{2}}\right)$ & $\mathbf{K}\left(\mathbf{g ~ m}^{-\mathbf{2}}\right)$ \\
\hline FARSANG, et al. 2014 & $0,11-0,78$ & $1,6-13,9$ \\
BIELDERS, et al. 2002 & $0,009-0,065$ & $0,002-0,128$ \\
STERK, et al. 1996 & 0,61 & 5,7 \\
\hline
\end{tabular}

Megállapítható, hogy egyazon talajtípusba eső, hasonló textúrájú szerkezetes talajok esetében a talajszerkezet állapota, valamint az arra ható karbonát- és humusztartalom meghatározó a deflációveszélyesség, valamint a talaj- és az elemelmozdulás mértéke szempontjából. 
A talajok agronómiai szerkezete nagymértékben befolyásolja tehát többek között az éghajlati változás okozta stressz-hatások talajtani következményeinek mérséklését, illetve azok súlyosbodását. A szélsőségessé váló időjárási helyzetek ráirányították a figyelmet arra, hogy a helytelenül alkalmazott múvelési eljárások, eszközök, illetve a csernozjom talajaink intenzív használata módosíthatja a talajszerkezetet, melynek egyik megjelenési formája a talaj felszíni rétegének elporosodása. A poros szerkezet kialakulása során a nagyobb makroaggregátumok mikroaggregátumokká esnek szét, $\mathrm{s}$ a létrejövő kisebb frakciók jobban ki vannak téve a szél általi elhordásnak.

Az emissziók, vagyis a mezőgazdasági parcellák felől a településeinket érő hatások mérséklése alapvetően a területhasználat, a gazdálkodási gyakorlat, illetve a defláció szabályozásán alapul. A „Best Management Practices” (BMPs) olyan kiválasztott eszközök csoportját jelenti, melyeket a talajdegradációval érintett területeken a széleróziót minimalizálva, a környezetet terhelő kibocsátási tevékenységek előtt, alatt és/vagy után alkalmazva csökkenthetik, vagy megszüntethetik a szennyezőanyagok kijutását a diffúz forrásokból. Ezen mezőgazdasági eredetủ terhelések azonban csak akkor számszerüsíthetők, ha a forrás (víz és/vagy szél) meghatározását követően az általa közvetített por, talaj- és szennyezőanyagterhelés nagyságrendjét és térbeli mozgását is nyomon követjük.

\section{Összefoglalás}

Kutatásunk során Magyarország két dél-alföldi réti csernozjom talajú területét vizsgáltuk azon céllal, hogy in situ körülmények között számszerüsítsük a különböző szélesemények által okozott talajveszteség mértékét, az ezzel együtt járó humusz- és tápanyagáthalmozás nagyságrendjét, valamint a két terület defláció érzékenységében tapasztalt különbségek okait.

Vizsgálati területeink Békés megyében, Makótól K-re mintegy 10 km-re, Apátfalva külterületén, valamint Csongrád megyében Szegedtöl ÉNy-ra 2 km-re helyezkedtek el. Kutatásunk célkitűzései az alábbiak voltak: terepi szélcsatornás mérésekre alapozott laboratóriumi mérések alapján különböző szerkezeti állapotú csernozjom talajokra meghatározni

- az indítósebességet,

- a szélerózióval áthalmozott szedimentben mért makroelem, és humuszanyag feldúsulását,

- valamint az ezekre ható talajtani tényezőket.

A hasonló mechanikai összetételü, Szeged és Apátfalva melletti réti csernozjom

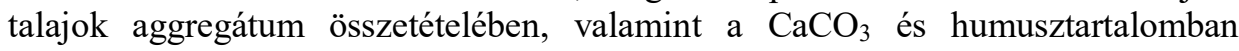
megfigyelhetö különbségek hatására a Szeged melletti csernozjom mintaterület talaja defláció érzékenyebb. A Szegedtől É-ra eső csernozjomokon 6,5-9,0 m s${ }^{-1}$ közötti indítósebesség értékeket mértünk, míg Apátfalván $13,0 \mathrm{~m} \mathrm{~s}^{-1}$ volt az indítósebesség értéke. Az apátfalvi terület talajának magasabb karbonát- és humusztartalma, valamint aggregátum összetételében mért magasabb morzsa arány az 
indítósebességérték növelésének irányába hat. A feltalajban a 0,5 mm-nél kisebb aggregátumok magasabb aránya következtében nemcsak kisebb indítósebesség értékeket, hanem nagyobb áthalmozódó talajmennyiséget, valamint ezzel együ̈t nagyobb mennyiségű humusz- és foszfor elmozdulást mértünk az egységesen 10-10 perces fújatási kísérleteink alkalmával a szegedi mintaterületen. Megállapítható tehát, hogy egyazon talajtípusba eső, s azonos textúrájú (homokos vályog) talajok esetében az aggregátum összetételben, valamint a $\mathrm{CaCO}_{3}$ és humusztartalomban megfigyelhető eltérések hatására jelentős különbségek tapasztalhatók a defláció érzékenység, az indítósebesség, a szediment szállítás módja és a humusz- és elemáthalmozás mértéke között.

Kulcsszavak: szélerózió, szélcsatorna, csernozjom talaj, aggregátum összetétel, talaj- és tápanyag-áthalmozás

\section{Köszönetnyilvánítás}

A kutatást az OTKA 1K 116981, „Különböző talajtípusok defláció érzékenységének in situ szélcsatorna kísérletekre alapozott vizsgálata, on site és off site hatások". programja támogatta.

\section{Irodalom}

BACH, M., 2008. Aolische Stofftransporte in Agrarlandschaftem. PhD Dissertation. Christian-Albrechts Universitat zu Kiel. Kiel

BARTUS M., BARTA K., SZATMÁRI J., FARSANG A., 2019. Csongrád megye talajainak szélcsatorna kísérletekre alapozott szélerózió veszélyeztetettség becslése Agrokémia és Talajtan. 68. (2) 225-242.

BIELDERS, C.L., RAJOT, J., AMADOU, M., 2002. Transport of soil and nutrients by wind in bush fallow land and traditionally managed cultivated fields in the Sahel. Geoderma. 109. 19-39.

BODOLAY I-NÉ, 1965. A talajok széleróziójának folyamata és dinamikája, Agrokémia és Talajtan. 14. (3-4) 311-320.

BODOLAY I.-NÉ, MÁTÉ, F., SzÜCS, L., 1976. A szélerózió hatása a Bácskai-löszháton, Agrokémia és Talajtan. 25. (1-2) 96-103.

BORSY Z., 1972. A szélerózió vizsgálata a magyarországi futóhomok területeken. Földrajzi Közlemények. 20. (2-3) 156-160.

BouZA M. E., J.C. SiLENZI, N.E. ECHEVERRÍA, M.P. De LuCiA, 2011. Analysis of erosive events for a soil in the southwest of Buenos Aires Province, Argentina. Aeolian Research. 3. (4) 427-435.

DöVÉNYI Z. (szerk.), 2010. Magyarország kistájainak katasztere. 2. átd. és bőv. kiad. Magyar Tudományos Akadémia. Budapest.

FARSANG A., 2016. A víz és szélerózió szerepe a talaj humusz- és elemtartalmának horizontális átrendeződésében. MTA Doktori Értekezés

FARSANG A., BARTA K., 2004. A talajerózió hatása a feltalaj makro- és mikroelem tartalmára. Talajvédelem. 268-276. 
FARSANG A., BARTUS M., BARTA K., SZATMÁRI J., 2013. Csernozjom talajok in situ széleróziós vizsgálata terepi szélcsatornával. Talajvédelem. 157-168.

FARSANG A., SZATMÁRI J., NÉGYeSI G., BARTUS M., BARTA K., 2011. Csernozjom talajok szélerózió okozta tápanyag-áthalmozódásának becslése szélcsatornakísérletekkel. Agrokémia és Talajtan. 60. (1) 87-102.

FARSANG A., R. DUTTMANN, M. BARTUS, J. SZATMÁRI, K. BARTA, G. BOZSÓ, 2013. Estimation of soil material transportaion by wind based on in situ wind tunnel experisemnts. Journal of Environmental Geography. 6. (3-4) 13-20.

GOOSSENS, D., OFFER, Z., LONDON, G., 2000. Wind tunnel and field calibration of five aeolian sand traps. Geomorphology. 35. 233-252.

JUNRAN L., G.S. OKIN, H.E. EPSTEIN 2009. Effects of enhanced wind erosion on surface soil texture and characteristics of windblown sediments. Journal of Geophysical Research-Biogeosciences. 2009. 114. G02003.

LARNEY, F. J., BULLOCK, M. S., JANZEN, H. H., ELLERT, B. H., OLSON, E. C. S., 1998. Wind erosion effects on nutrient redistribution and soil productivity. Journal of Soil and Water Conservation. 53. (2) 133-140.

LEYS, J., MCT AINSH, G., 1994. Soil loss and nutrient decline by wind erosion - cause for concern. Australian Journal of Soil and Water Conservation. 7. (3) 30-35.

LÓKI J., 2000. The study of wind erosion on different soil by wind tunnel. In: Anthropogenic aspects of landscape transformations. 1. Proceeding of Hungarian-Polish Symposium. (ed.: LÓKI J. \& SzABÓ J.) Debrecen. 37-44.

LÓKI J., 2003a. A növényzet szélerózió elleni védőhatásának vizsgálata szélcsatornában. Környezetvédelmi mozaikok. Debrecen. 291-306.

LÓKI J., 2003b. A szélerózió mechanizmusa és magyarországi hatásai. MTA doktori értekezés. Debrecen.

LÓKI J., SZABÓ J., 1996. Neuere Windkanaluntersuchungen der Deflationssensibilität von Böden des Ungarischen Tieflandes. Zeitschrift für Geomorphologie. 40. Berlin-Stuttgart. 145-159.

LÓKI J., SZABÓ J., 1997. Az alföldi talajok deflációérzékenységi vizsgálata szélcsatornában. Regionális Agrárkutatási és Vidékfejlesztési Workshop. Kompolt. 73-83.

LÓKI J., SCHWEITZER F., 2001. Fiatal futóhomokmozgások kormeghatározási kérdései - Duna-Tisza közi régészeti feltárások tükrében. Acta Geographica Geologica et Meteorologica Debrecina. XXXV. 175-183.

MARSI, Z., ZÖBISCH, M., BrugGeman, A., HAYeK, P., KARdous, M., 2003. Wind erosion in a marginal mediterranean dryland area: a case study from the Khanasser Valley, Syria. Earth Surface Processes and Landforms. 28. $1211-1222$.

MENDEZ M.J., R. FunK, BUSCHIAZZO, D.E., 2011. Field wind erosion measurements with Big Spring Number Eight (BSNE) and Modified Wilson and Cook (MW AC) samplers. Geomorphology. 129. (1-2) 43-48.

MEZÖSI G., SZATMÁRI J., 1998. Assessment of wind erosion risk on the agricultural area of the southern part of Hungary. Journal of Hazardous Materials. 61. $139-153$. 
Movahedan M., AbBasi N., Keramati M., 2012. Wind erosion control of soils using polymeric materials. Eurasian Journal of Soil Science. 2. 81-86.

MSZ-08-0205:1978 „A talaj fizikai és vízgazdálkodási tulajdonságainak vizsgálata” c. Magyar Szabvány

MSZ 08-0206-2:1978 „A talaj egyes kémiai tulajdonságainak vizsgálata.” c. Magyar Szabvány

MSZ 08-0458:1980 „A talaj összes nitrogéntartalmának meghatározása” c. Magyar Szabvány

MSZ 21470/2:1981 „Környezetvédelmi talajvizsgálatok. Talajminta előkészítése, nedvességtartalom, elektromos vezetés és $\mathrm{pH}$ meghatározása" c. Magyar Szabvány

MUCSI L., SZATMÁRI J., 1998. Landscape changes of a blown sand surface on the Great Hungarian Plain. The problems of landscape ecology. III. Warsaw. $215-222$

NEEMANN W., 1991. Bestimmung des Bodenerodierbarkeitsfaktors für winderosionsgefahrdete Böden Norddeutschlands - Ein Beitrag zur Quantifizierung der Bodenverluste. Schweizerbart. Hannover.

RIKSEN, M., 2004. Off-site effects of wind erosion on agricultural land in NW Europe. In: Wind erosion and dust dynamics: observations, simulations, modelling (ed.: GoOSSENS, D. AND RIKSEN, M.) ESW Publications, Department of Environmental Sciences, Erosion and Soil and Water Conservation Group. Wageningen University. 103-122.

Sterk, G., HerrmanN, L., BAtiono, A., 1996. Wind-blown nutrient transport and soil productivity changes in Southwest Niger. Land degradation \& development. 7. 325-335.

SZATMÁRI J., 1997. Evaluation of wind erosion risk on the SE part of Hungary. Acta Geographica Szegediensis. XXXVI. 121-135.

SZATMÁRI J., 2005. The evaluation of wind erosion hazard for the area of the DanubeTisza Interfluve using the Revised Wind Erosion Equation. Acta Geographica Szegediensis. XXXVIII. 84-93.

VAN DONK, S. J., SKIDMORE, E. L. 2001. Field experience and evaluating wind erosion models. Annals of Arid Zone. 40. (3) 281-302.

ZobeCK, T., Fryrear, D.W., 1986. Chemical and Physical characteristic of windblown sediment. Transaction of the ASAE. 29. 1037-1041.

Zobeck, T., Fryrear, D.W., Petit, R.D., 1989. Management effects on winderoded sediment and plant nutrients. Journal of Soil \& Water Conservation. 44. 160-163. 


\section{Exploring the differences in soil, humus and nutrient accumulation caused by wind erosion on chernozem soils with different structural properties by field wind tunnel experiments}

*Andrea FARSAng, Károly BARTA, József SzATMÁRI, Máté BARTUS

Department of Geoinformatics, Physical and Environmental Geography, Univertsity of Szeged, Szeged

\section{Summary}

In our research, two Chernozem soil areas were examined in the southern part of the Great Hungarian Plain in order to quantify the amount of the soil loss, humus and nutrient transport caused by different wind events and in order to show the causes of the differences in the sensitivity of deflation between the two areas.

Our study areas were located in Békés County, one of them was near Apátfalva, about $10 \mathrm{~km}$ east of Makó, and the other one was $2 \mathrm{~km}$ northeast of Szeged in Csongrád County. Our in situ wind tunnel experiments were accomplished on 2-4 June 2011 at Apátfalva and in July 2013 in Szeged. The objectives of our research were the followings:

- determination of the enrichment ratios for humus, macro- and microelements in the wind eroded sediments in the case of Chernozem soils with different structures based on field experiments and laboratory measurements;

- determination the affecting actual soil factors;

- estimation of soil loss and element rearrangement trends on Chernozem arable lands under different wind velocity on plot scale.

Because of the differences in the aggregate size distribution, $\mathrm{CaCO}_{3}$ and humus content, Chernozem soil near Szeged is more sensitive to deflation than near Apátfalva. Threshold friction velocity was measured between 6.5 and $9.0 \mathrm{~m} \mathrm{~s}^{-1}$ near Szeged, while the same parameter was $13.0 \mathrm{~m} \mathrm{~s}^{-1}$ at Apátfalva. The higher carbonate and humus content and the higher crumb ratio of the soil on the Apátfalva area result increasing threshold friction velocity. Due to the higher proportion of aggregates smaller than $0.5 \mathrm{~mm}$ in the topsoil, we have measured not only lower threshold friction velocities, but also a larger quantity of transported soil and a larger humus and phosphorus loss during the uniform 10-10 minute long wind tunnel experiments in the Szeged sample area. It can be concluded that even in spite of the same soil type and same texture there are significant differences between deflation sensitivity, threshold friction velocity, sediment transport mode, humus and nutrient transportation because of the significant differences in aggregate size distribution, $\mathrm{CaCO}_{3}$ and humus content.

It means that the agronomic structure of the soils greatly influences the mitigation and aggravation of the soil the stress effects caused by climate change. Extreme weather situations have drawn attention to the fact that improperly applied cultivation methods, tools, and overuse of Chernozem soils can modify the soil 
structure. One of the most serious affect is the dusting of the surface layer of the soil. During this process the larger macroaggregates disintegrate into microaggregates and the resulting smaller fractions are more exposed to wind erosion.

The dust load affecting our settlements is mainly originated from arable lands. The mitigation of this emission is fundamentally based on the regulation of land use, farming practices and deflation. "Best Management Practices" (BMPs) mean a group of selected tools that can reduce or eliminate the transport of pollutants from diffuse sources before, during and/or after agricultural activities. However, these diffuse agricultural loads caused by wind erosion can only be quantified if the magnitude and spatial movement of the dust and pollutants is monitored.

Keywords: wind erosion, wind tunnel, chernozem soil, aggregate size distribution, soil and nutrient accumulation

\section{Tables and figures}

Table 1. „On-site” and „off-site” effects of deflation events (modified by FARSANG (2016) after GoOSSENS, et al. (2000) and BACH (2008))

Table 2. Basic soil parameters of experimental plots in Apátfalva and Szeged. (1. salt content; 2 . carbonate content; 3 . humus content; 4 . number of heaviness)

Table 3. Aggregate size distribution of the original topsoil on the study plots $(\mathrm{m} / \mathrm{m} \%$, Apátfalva $\mathrm{n}=3$, Szeged $\mathrm{n}=10)$. (1. surface; 2 . statistical variance)

Table 4. Comparison of the amount of displaced soil material, humus, element content and enrichment ratios on the experiment plots (Chernozems near Apátfalva and Szeged). (1. critical threshold speed $\left(\mathrm{m} \mathrm{s}^{-1}\right)$; 2. displaced soil (average) $\left(\mathrm{g} \mathrm{m}^{-2}\right) ; 3$. concentration in trapped sediment; 4.enrichment ratio; 5. total humus / element displacement $\left(\mathrm{g} \mathrm{m}^{-2}\right)$

Table 5. Comparison of wind eroded nutrient $(\mathrm{P}, \mathrm{K})$ loss measured by different

Figure 1. The main modes of transport for wind erosion in terms of particle diameter and transport distance. (1. floatation; 2. bouncing; 3. rolling; 4. scale)

Figure 2. Locations of mobile wind tunnel experiments: Apátfalva and Szeged

Figure 3. The wind tunnel: 1: fan, 2: laminator, 3: test sections, 4: sediment trap, 5: exit with various traps

Figure 4. Typical wind profiles of the measurements (Apátfalva), isoline representation of the wind speed $\left(\mathrm{m} \mathrm{s}^{-1}\right)$ in the cross section of the wind tunnel above the bare ground surface (1. height; 2 . width)

Figure 5. Instrument set applied in the experiment - top view and side view (wind tunnel, scale, MWAC traps, WAST traps)

Figure 6. Wilson and Cooke trap (GoOSSENS, et al. (2000): the collecting container (left) and the whole set in Apátfalva (right))

Figure 7. The 3 WAST traps in different heights

Figure 8. Particle size distribution of the Chernozem in Apátfalva. (1. particle size; 2. \% by weight) 
Figure 9. Particle size distribution of the Chernozem near Szeged. (1. particle size; 2. \% by weight)

Figure 10. Relationship between the median aggregate diameter (D50 (mm)) and the threshold friction velocity. (1. wind speed ( $\mathrm{m} \mathrm{s}^{-1}$ ), BARTUS, et al. (2019))

Open Access nyilatkozat: A cikk a Creative Commons Attribution 4.0 International License (https://creativecommons.org/licenses/by/4.0) feltételei szerint publikált Open Access közlemény, melynek szellemében a cikk bármilyen médiumban szabadon felhasználható, megosztható és újraközölhető, feltéve, hogy az eredeti szerző és a közlés helye, illetve a CC License linkje és az esetlegesen végrehajtott módosítások feltüntetésre kerülnek. (SID_1) 